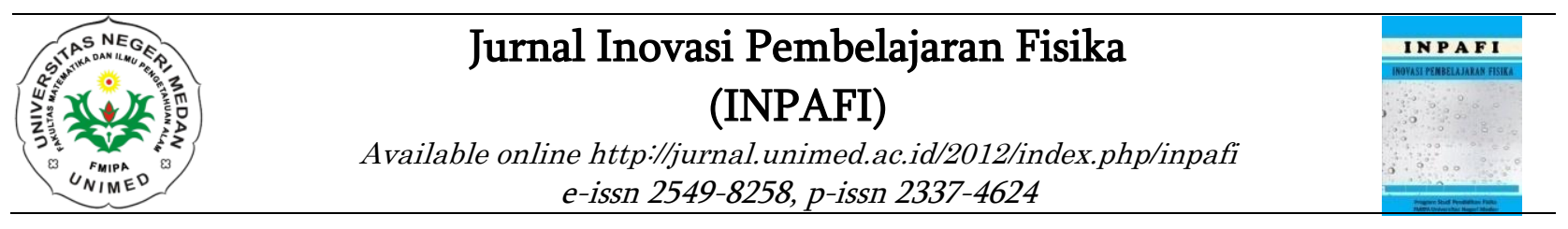

\title{
PENGARUH MODEL PEMBELAJARAN INQUIRY TRAINING TERINTEGRASI POWERPOINTTERHADAP KETERAMPILAN PROSES SAINS DI KELAS X SEMESTER II SMA DHARMA PANCASILA T.P 2017/2018
}

\author{
Rima Nilmalasari dan Karya Sinulingga \\ Jurusan Fisika FMIPA Universitas Negeri Medan \\ rimanilmala27@gmail.com, karyasinulinggakarya@yahoo.co.id \\ Diterima: Desember 2018. Disetujui: Januari 2019. Dipublikasikan: Februari 2019
}

\begin{abstract}
ABSTRAK
Penelitian ini bertujuan untuk mengetahui pengaruh model pembelajaran inquiry trainingterhadap keterampilan proses sains pada materi pokok Momentum, Impuls dan Tumbukan di kelas X SMA Dharma Pancasila T.P. 2017/2018.Jenis penelitian yang digunakan adalah quasi eksperimen dengan desain penelitian Control Group Pre-test Posttest. Populasi dalam penelitian adalah seluruh siswa kelas X SMA Dharma Pancasila Medan yang terdiri dari 4 kelas. Pengambilan sampel dilakukan dengan cara random sampling yaitu kelas X MIA 1 dengan jumlah sampel sebanyak 30 orang sebagai kelas eksperimen yang diberi perlakuan model inquiry trainning terintegrasi powerpoint dan X MIA 2 dengan jumlah sampel sebanyak 30 orang sebagai kelas kontrol dengan pembelajaran konvensional. Instrumen yang dilakukan berbentuk essai tes sebanyak 7 soal yang telah divalidasi oleh validator. Berdasarkan hasil pengolahan data post test diperoleh nilai rata-rata kelas eksperimen 78,92 dan nilai rata-rata kelas kontrol 68,67. Hasil penelitian yang peroleh bahwa ada perbedaan nilai rata - rata dan aktivitas yang signifikan akibat pengaruh dari model pembelajaran inquiry training terintegrasi powerpoint terhadap keterampilan proses sains siswa pada materi pokok Momentum, Impuls dan Tumbukan kelas X SMA Dharma Pancasila Medan T.P 2017/2018.
\end{abstract}

Kata Kunci: Model pembelajaraninquiry training, keterampilan proses sains, powerpoint

\begin{abstract}
This study aims to determine the effect of model Inquiry Training to science process skills on the subject matter of momentum, impulse and collision in class X SMA Dharma Pancasila T.P 2017/2018.The type of this research is quasi experiment with two group pretest-posttest design research. The population of this study is all students of class X SMA Dharma Pancasila Medan consisting of 4 classes. Sampling was done by cluster random sampling that is class $\mathrm{X}$ MIA 1 as experiment class which amounted to 30 people were given treatment inquiry trainning integrated powerpoint and Class X MIA 2 as control class which amounted to 30 people who were given conventional. Instruments that performed the test as much as essai shaped 7 questions have been validated by the validator. Based on the results of the data processing post test obtained average value of experimental class 78.92 and average value of control class 68.67. The research results obtained so it can be concluded that there is a significant difference due to the influence of a model of integrated inquiry training learning
\end{abstract}


powerpoint skills against the process of science students in the subject matter of Momentum, Impulse and collision of class X SMA Dharma Pancasila MedanT.P 2017/2018.

Keywords: problem basic learning, conventional learning, student physics problem solving ability

\section{PENDAHULUAN}

Menurut Hidayat dan Harahap (2015) abad 21 merupakan abad ilmu pengetahuan dan teknologi, karena itu kita dihadapkan pada suatu situasi dimana ilmu pengetahuan dan teknologi berubah dan berkembang sangat pesat. Menghadapi perubahan yang sangat pesat tersebut maka dibutuhkan sumber daya manusia (SDM) yang memiliki daya saing tinggi, kreatif, handal dan berkualitas agar mampu mengatasi bermacam-macam kemungkinan penyelesaian terhadap suatu masalah dan perubahan. Tuntutan SDM yang diharapkan tidak sesuai dengan kenyataan yang ada. Menurut data Human Development Report versi UNDP tahun 2013, peringkat HDI (HumanDevelopment Index) Indonesia berada pada peringkat 121 dari 187 negara. Sementara itu hasil penilaian Trends in International Mathematicsand Science Study (TIMSS), suatu studi internasional yang diselenggarakan setiap 4 tahun dengan tujuan mengetahui perkembangan kemampuan sains bagi para pelajar di berbagai negara, tahun 2011 menempatkan Indonesia di peringkat 38 dari 42 negara. Hal ini menunjukkan bahwa kualitas SDM dan kemampuan sains siswa di Indonesia masih jauh dibawah rata-rata dari negara lain.

Pemerintah telah menyelenggarakan perbaikan-perbaikan peningkatan mutu pendidikan pada berbagai jenis dan jenjang pendidikan untuk mencapai tujuan pendidikan nasional. Fakta dilapangan belum menunjukkan hasil yang memuaskan. Masalah utama dalam pembelajaran pada pendidikan formal (sekolah) dewasa ini adalah masih rendahnya daya serap peserta didik. Hal ini tampak dari rerata hasil belajar peserta didik yang senantiasa masih jauh dari yang diharapkan. Prestasi ini tentunya merupakan hasil kondisi pembelajaran yang masih bersifat konvensional dan tidak menyentuh ranah dimensi peserta didik itu sendiri (Sinaga dan Hutahahean, 2016).
Menurut peneliti sebelumnya Pani dan Tarigan (2016) diperoleh perbedaan Keterampilan proses sains siswa dengan menggunakan model pembelajaran Inquiry Training tergolong tuntas, yaitu 23 orang yang tuntas dan secara kelas tidak tuntas. Sebelum diberikan perlakuan rata-rata pretes sebesar 46.16 dan setelah diberikan perlakuan rata-rata postes sebesar 74.46. Ada perbedaan keterampilan proses sains siswa setelah menerapkan model inquiry training dengan pembelajaran konvesional.

Menurut Dinigrum dan Harahap (2017) mengatakan keterampilan proses sains siswa dengan menggunakan model inquiry training khususnya pada materi fluida dinamis memberikan nilai rata-rata dengan kategori sangat baik. Aktivitas siswa yang dikembangkan dari model inquiry training memberi informasi bahwa dapat mengembangkan keaktifan siswa dalam proses pembelajaran ditinjau dari hasil dengan kategori rata-rata aktivitas di setiap pertemuan dinyatakan aktif.

Perbedaan penelitian ini dengan penelitian sebelumnya adalah tempat penelitian, sampel penelitian, materi penelitian, waktu pelaksanaan penelitian serta berbantuan media yang akan digunakan. Penelitian ini menggunakan materi Momentum, Impuls dan Tumbukan di SMA Swasta Dharma Pancasila terintegrasi powerpoint. Kurangnya minat belajar siswa terhadap pelajaran fisika menunjukkan bahwa pembelajaran yang dilakukan selama ini belum efektif.

Kelemahan dari penelitian sebelumnya adalah penggunaan waktu dalam melakukan penelitian masih terlalu banyak sehingga tidak menyisakan waktu bagi guru dan siswa untuk berdiskusi lebih lama. Berdasarkan kelemahan tersebut maka diperlukan media untuk mengefisienkan waktu agar dalam melakukan penelitian ini tidak terlalu banyak menghabiskan waktu sehingga masih tersisa waktu bagi siswa dan guru untuk berdikusi. Salah satu media yang paling cocok digunakan adalah media 
Rima Nilmalasari dan Karya Sinulingga; Pengaruh Model Pembelajaran Inquiry Training Terintegrasi Powerpoint Terhadap Keterampilan Proses Sains Di Kelas X Semeseter II SMA Dharma Pancasila T.P 2017/2018

powerpoint yang lebih bersifat realistis dan mampu mengefisienkan waktu sehingga memberikan kemudahan bagi siswa untuk lebih memahami suatu materi. Penggunaan media powerpoint ini yang akan menjadi perbedaan antara penelitian yang akan dilakukan dengan penelitian sebelumnya.

Berdasarkan hasil observasi study pendahuluan dengan menggunakan angket menyimpulkan bahwa masih banyak peserta didik yang tidak menyukai pelajaran fisika. siswa menggangap pelajaran fisika hanya berhubungan dengan rumus-rumus saja sehingga peserta didik tidak mengerti apa yang dijelaskan oleh gurunya. Pada proses pembelajaran fisika masih cenderung berbasis pada hafalan teori dan rumus-rumus dan tidak didasarkan pada pengalaman siswa melakuksan eksperimen seperti mengamati, merumuskan hipotesis, memprediksi, menemukan pola dan hubungan, berkomunikasi secara efektif, merancang percobaan, mengukur dan menghitung yang menyebabkan rendahnya keterampilan proses sains (KPS) pada siswa. Didalam pembelajaran fisika siswa bukan hanya menghafal fisika secara teori tapi siswa juga harus memiliki skill atau keterampilan dalam menggunakan konsep-konsep pada fisika ataupun juga terampil dalam proses praktikum.

Mengatasi rendahnya keterampilan proses siswa perlu digunakan suatu metode atau model pembelajaran yang berpusat pada siswa. Salah satu model pembelajaran yang dapat digunakan adalah model pembelajaran inquiry training. Menggunakan model pembelajaran inquiry training diharapkan proses pembelajaran tidak lagi sekedar transfer pengetahuan dari guru kepada siswa tetapi merupakan proses perolehan konsep dari keterlibatan siswa secara langsung. Penggunaan model pembelajaran inquiry training ini diharapkan mampu meningkatkan keterampilan proses sains (KPS) siswa.

Menurut Joyce,dkk (2009), model pembelajaran inquiry training dirancang untuk membawa siswa secara langsung ke dalam proses ilmiah melalui latihan-latihan yang dapat memadatkan proses ilmiah tersebut ke dalam periode waktu yang singkat. Tujuannya adalah membantu siswa mengembangkan disiplin dan mengembangkan keterampilan intelektual yang diperlukan untuk mengajukan pertanyaan dan menemukan jawabannya berdasarkan rasa ingin tahunya.

Saran-saran dari Pani dan Tarigan (2016) juga menjadi salah satu alasan peneliti untuk meneliti kembali topik ini. Adapun saran-saran tersebut yaitu : kembali mengecek alat dan bahan yang akan digunakan dalam praktikum supaya pembelajaran dapat berlangsung dengan efektif dan efisien. Kemudian menambah jumlah observer, agar pengawasan lebih maksimal ketika pembelajaran berlangsung karena setiap observer terfokus untuk mengawasi satu atau dua kelompok saja sehingga pembelajaran dapat berlangsung kondusif.

Berdasarkan latar belakang yang telah dipaparkan, penulis bermaksud melakukan penelitian yang bertujuan untuk mengetahui pengaruh model pembelajaran inquiry training terhadap keterampilan proses sains pada materi pokok Momentum, Impuls dan Tumbukan di kelas X SMA Dharma Pancasila T.P. 2017/2018.

\section{METODE PENELITIAN}

Penelitian ini dilaksanakan di SMA Swasta Dharma Pancasila Medan dan pelaksanaannya pada semester genap tahun ajaran 2017/2018. Populasi dalam penelitian ini adalah seluruh siswa kelas X SMA Swasta Dharma Pancasila T.P 2017/2018 yang terdiri atas 4 kelas. Sampel dalam penelitian ini terdiri dari dua kelas yaitu kelas eksperimen diterapkan model pembelajaran inquiry training dan kelas kontrol diterapkan pembelajaran konvensional. Pengambilan sampel dilakukan secara random sampling. Random sampling adalah pemilihan kelompok secara acak untuk dijadikan sebagai sampel dimana setiap sampel memiliki peluang yang sama untuk dijadikan sampel. Variabel penelitian ini terdiri atas dua jenis yaitu variabel bebas adalah penerapan model pembelajaran inquiry training dan pembelajaran konvesional dan variabel terikat dalam penelitian ini adalah keterampilan proses sains siswa kelas X SMA 
Dharma Pancasila pada materi pokok momentum dan impuls.

Jenis penelitian ini adalah penelitian quasi eksperimen. Desain penelitian yang digunakan adalah two group pretes-postes seperti yang ditunjukkan pada Tabel 1:

Tabel 1.

Desain Penelitian (Two Group Pretes-Postes Design)

\begin{tabular}{|c|c|c|c|}
\hline Sampel & Pretes & Perlakuan & $\begin{array}{c}\text { Post } \\
\text { es }\end{array}$ \\
\hline $\begin{array}{c}\text { Kelas } \\
\text { Eksperimen }\end{array}$ & $\mathrm{O}$ & $\mathrm{X}_{1}$ & $\mathrm{O}$ \\
\hline $\begin{array}{c}\text { Kelas } \\
\text { Kontrol }\end{array}$ & $\mathrm{O}$ & $\mathrm{X}_{2}$ & $\mathrm{O}$ \\
\hline
\end{tabular}

\section{Keterangan:}

$\mathrm{O}$ : Instrumen penelitian

X1 : Model Pembelajaran Inquiry Training

X2 : Pembelajaran Konvensional

\section{HASIL DAN PEMBAHASAN}

\section{a. Hasil Penelitian}

Data dari hasil penelitian ini berupa keterampilan proses sains siswa yaitu nilai pretest dan post-tes, hasil observasi aktivitas siswa di kelas eksperimen selama proses pembelajaran.

Peneliti terlebih dahulu memberika tes uji kemampuan awal (pretes) pada kedua kelas yang bertujuan untuk mengetahui apakah kemampuan awal siswa pada kedua kelas sama atau tidak. Berdasarkan hasil penelitian diperoleh nilai rata-rata pretes siswa pada kelas eksperimen sebelum diberi perlakuan dengan menggunakan model pembelajaran inquiry training sebesar 51,47 dengan standar deviasi 6,03. Di kelas kontrol diperoleh nilai rata-rata pretes siswa sebesar 49,34 dengan standar deviasi 7,45 dan nilai rata - rata gabungan kedua kelas sebesar 50,41 dengan standar devasi 6,82. Setelah memperoleh data hasil nilai pre-test dari kedua sampel, maka dilakukan pengujian analisis data dengan mengunakan uji kesamaan (uji t) rata rata pre-test dengan syarat berdistribusi normal dan homogenitas dan berhipotesis. Maka dilakukan pengujian uji normalitas, uji homogenitas dan uji kesamaan (uji t).
Berdasarkan hasil uji $\mathrm{t}$ statistik dalam uji kesamaan kedua kelas dalam diagram batang dapat ditunjukkan pada gambar 4.1.

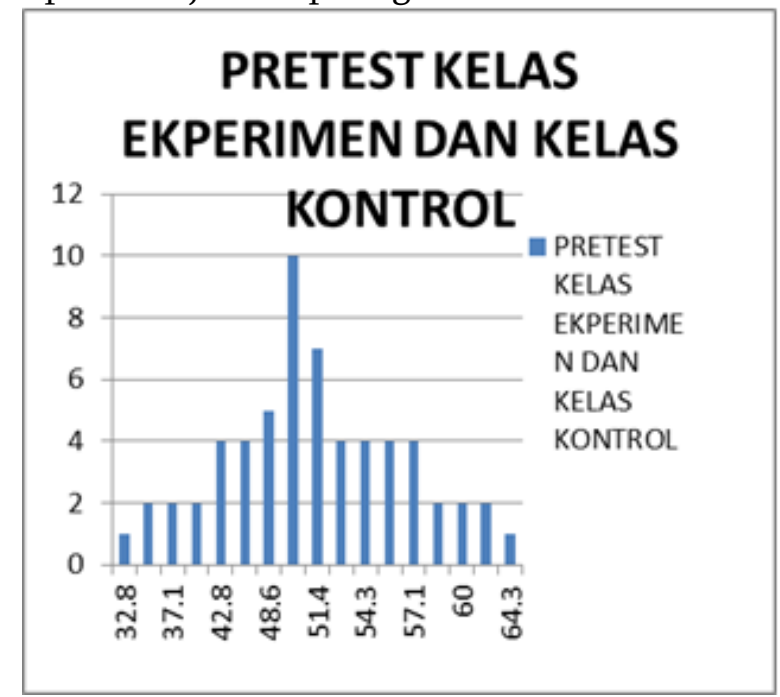

Gambar 4.1. Diagram Batang Nilai Pre test Kedua Kelas

Diperoleh kesimpulankemampuan awal siswa pada kelas kontrol sama dengan kemampuan awal siswa pada kelas eksperimen.

Hasil postes kelas eksperimen memiliki nilai rata-rata 78,92 sedangkan kelas kontrol memperoleh nilai rata-rata 68,67. Pengujian hipotesis data post test dilakukan dengan menggunakan uji t. Pengujian digunakan untuk mengetahui apakah ada perbedaaan karena pengaruh penerapan model pembelajaran inquiry training terintegrasi powerpoint terhadap keterampilan proses sains siswa pada materi pokok Momentum dan Impuls. Berdasarkan hasil uji t statistik dalam uji beda kedua kelas dalam diagram batang dapat ditunjukkan pada gambar 4.2.

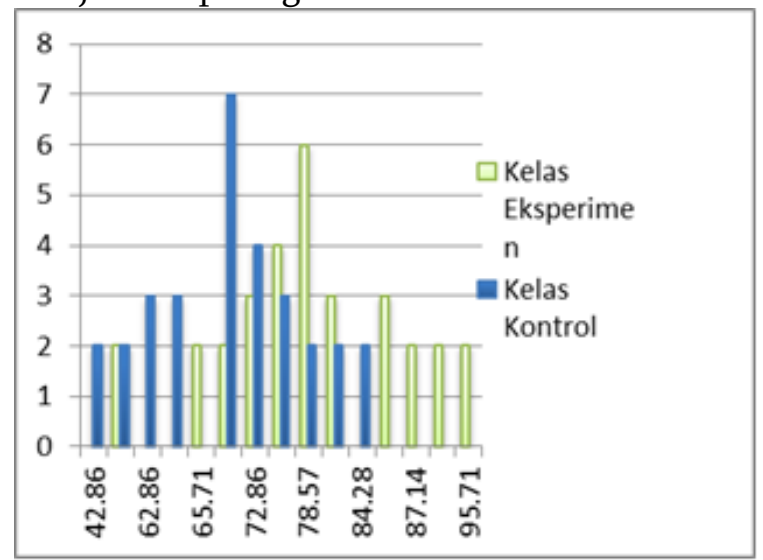

Gambar 4.2 Diagram Batang Data Post test Kelas Kontrol dan Kelas Eksperimen 
Rima Nilmalasari dan Karya Sinulingga; Pengaruh Model Pembelajaran Inquiry Training Terintegrasi Powerpoint Terhadap Keterampilan Proses Sains Di Kelas X Semeseter II SMA Dharma Pancasila T.P $2017 / 2018$

Dari perbedaan nilai rata - rata kedua kelas tersebut dapat disimpulkan bahwa model inquiry training terintegrasi powerpoint memiliki pengaruh terhadap keterampilan proses sains siswa lebih baik dibandingkan pembelajaran konvesional pada materi pokok Momentum dan impuls SMA Swasta Dharma Pancasila Medan T.A 2017/2018.

Aktivitas keterampilan proses sains siswa selama proses pembelajaran yang telah di lakukan SMA Swasta Dharma Pancasila Medan T.A 2017/2018, pengamatan aktivitas KPS siswa dilakukan tiga kali pertemuan setelah melakukan pretes. Observasi aktivitas KPS ini hanya dilakukan dikelas eksperiment. Berdasarkan perhitungan presentase indikator keterampilan proses sains dapat dilihat pada gambar 4.3.

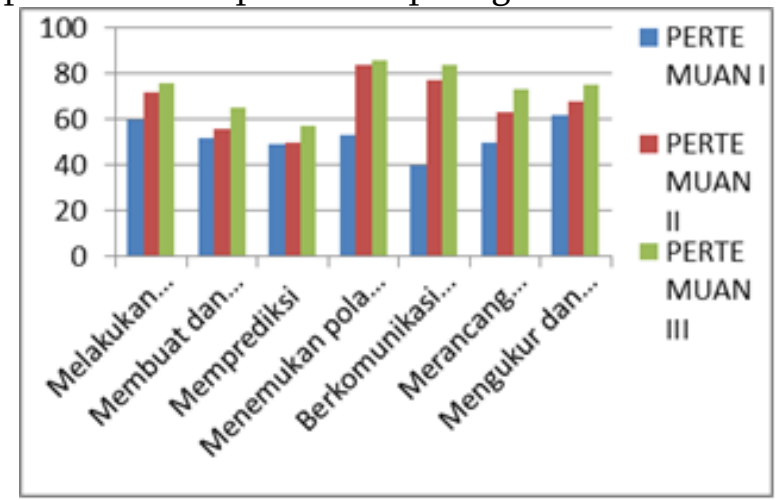

Gambar 3. Data posttes kelas eksperimen dan kontrol

keterampilan proses sains siswa pada pre-test di kedua kelas dapat dilihat pada tabel 1 .

Tabel 1. Peningkatan nilai rata-rata aktivitas keterampilan proses sains siswa kelas eksperimen pada pertemuan I, II, dan III

\begin{tabular}{|c|c|c|c|c|}
\hline \multirow{2}{*}{ No } & $\begin{array}{c}\text { Aspek Keterampilan } \\
\text { Proses Sains }\end{array}$ & \multicolumn{3}{|c|}{ Kelas Eksperimen } \\
\cline { 3 - 5 } & $\%$ & $\%$ & $\%$ \\
\hline 1 & $\begin{array}{c}\text { Melakukan Pengamatan } \\
\text { (Observasi) }\end{array}$ & 33,33 & 40 & 42,22 \\
\hline 2 & $\begin{array}{c}\text { Membuat dan menguji } \\
\text { hipotesis }\end{array}$ & 28,89 & 31,11 & 36,11 \\
\hline 3 & Memprediksi & 27,22 & 26,11 & 31,67 \\
\hline 4 & $\begin{array}{c}\text { Menemukan pola dan } \\
\text { hubungan }\end{array}$ & 29,44 & 46,67 & 47,78 \\
\hline
\end{tabular}

\begin{tabular}{|c|c|c|c|c|}
\hline 5 & $\begin{array}{c}\text { Berkomunikasi secara } \\
\text { efektif }\end{array}$ & 22,22 & 42,77 & 46,67 \\
\hline 6 & Merancang percobaan & 27,78 & 35 & 40,56 \\
\hline 7 & $\begin{array}{c}\text { Mengukur dan } \\
\text { menghitung }\end{array}$ & 34,44 & 37,78 & 41,67 \\
\hline
\end{tabular}

\section{b. Pembahasan}

Peningkatan keterampilan proses sains siswa kelas eksperimen bila dibandingkan kelas kontrol terjadi perbedaan. Peningkatan ini terjadi karena siswa semakin terampil dalam melaksanakan pembelajaran sesuai dengan aturan pembelajaran inquiry training.

Adanya perbedaan keterampilan proses sains tersebut dikarenakan adanya pengaruh model inquiry training terintegrasi powerpoint terhadap keterampilan proses sains siswa. Hal tersebut menunjukkan bahwa pembelajaran menggunakan inquiry training terintegrasi powerpoint lebih baik dari pembelajaran konvensional, karena di setiap fase inquiry training dapat mengembangkan aktivitas keterampilan mengamati, mengumpulkan dan mengolah data, merumuskan penjelasan, mengidentifikasi dan mengontrol variabel, membuat dan mnguji hipotesis, merancang percobaan dan memberikan kesimpulan. Di kelas eksperimen dibantu dengan media powerpoint yang berisi tambahan animasi ataupun gambar - gambar yang menarik perhatian siswa. Di setiap fase inquiry training dirancang untuk membawa siswa secara langsung ke dalam proses ilmiah, dari fase inquiry training aktivitas siswa lebih baik terhadap indikator keterampilan proses sains. Indikator keterampilan proses sains terdiri dari 7 aspek yaitu melakukan pengamatan (observasi), membuat dan menguji hipotesis, memprediksi, menemukan pola dan hubungan, berkomunikasi secara efektif, merancang percobaan, mengukur dan menghitung.

Model pembelajaran inquiry training terintegrasi powerpoint memberikan kesempatan pada siswa bereksplorasi mengumpulkan dan menganalisis data untuk memecahkan masalah karena seiringan dengan 
indikator kedua pada KPS yaitu membuat dan menguji hipotesis membuat siswa lebih mudah dalam menemukan alternatif pemecahan masalah. Siswa dalam hal ini aktif dan antusias untuk bekerja sama dengan teman satu kelompok dalam menyelesaikan masalah yang telah diberikan oleh peneliti karena seiringan dengan indikator kelima pada KPS yaitu berkomunikasi secara efektif membuat siswa juga tertarik dan aktif saat berdiskusi dan mengeluarkan pendapat yang berbeda saat diadakan diskusi antar kelompok.

Metode yang digunakan pada pembelajaran konvesional jarang seklai tergambar keterampilan - keterampilan seperti fase inquiry training dan indikator keterampilan proses sains karena pembelajaran konvensional hanya menggunakan metode ceramah dan penungasan mengerjakan soal -soal yang sebenarnya pembelajaran fisika tidak hanya menuntut siswa untuk mengerti rumus - rumus tapi juga harus dibina keterampilan proses sains siswa dan membuat pemebelajaran lebih bermakna, menarik, aktif bagi siswa itu sendiri.

Hal ini sesuai dengan teori yang dikemukakan oleh Harlen dan Jos (1992) bahwa siswa yang memiliki keterampilan proses sains yang baik karena dibawa secara langsung ke dalam proses/kegiatan ilmiah sehingga mampu melakukan sesuatu hal yang baru dan mampu mengembangkan kemampuan mendasar yang dimilikinya karena siswa diberi kesempatan untuk melakukan atau bereksperimen bukan hanya sekedar membicarakan sesuatu tentang sains.

Model pembelajaran inquiry training yang juga sangat menguntungkan karena memberi peluang sama kepada semua siswa, baik siswa yang memiliki kemampuan rendah, sedang maupun tinggi untuk dapat menemukan materi melalui praktikum tanpa adanya perbedaan. Dengan model pembelajaran inquiry training siswa lebih berani berbicara didepan kelas.Salah satu contoh saat siswa diberikan masalah mengenai materi hubungan momentum dan impuls dalam kehidupan sehari - hari, siswa secara berkelompok dan berkerjasama melakukan eksperimen menyelidiki bagaimana hubungan momentum dan impuls dalam kehidupan sehari - hari terjadi. Hal inilah yang menyebabkan model pembelajaran inquiry training memiliki hasil belajar dalam arti keterampilan proses sains yang lebih baik dari pada pembelajaran konvensional.

Model pembelajaran inquiry training diperoleh hasil belajar yaitu keterampilan proses sains siswa juga didukung dengan penggunaan powerpoint. Peran penting powerpoint pada saat pembelajaran adalah menarik perhatian siswa, membangun pemahaman serta intuisi untuk fenomena yang bersifat abstrak mengenai materi momentum dan impuls. Penggunaan powerpoint juga dapat memberikan pengalaman menarik kepada siswa pada saat pembelajaran, mendidik siswa agar memiliki pola berpikir kontruktivisme, membuat pembelajaran lebih menarik karena siswa dapat belajar sekaligus bermain pada simulasi tersebut dan memvisualisasikan konsep momentum dan impuls.

Hal ini sesuai dengan hasil penelitian Marpaung dan Sahyar (2016)dengan menggunakan judul penelitian efek model pembelajaran inquiry training berbantuan peta konsep dan sikap ilmiah terhadap hasil belajar keterampilan proses sains siswa.

Hasil penelitian ditemukanbahwa pembelajaran dengan model pembelajaran inquiry training berbantuan peta konsep dan sikap ilmiah terhadap hasil belajar keterampilan proses sains siswa. Keterampilan proses sains siswa pada kelompok siswa yang mempunyai sikap ilmiah diatas rata-rata dengan nilai ratarata 78,3 lebih baik dibandingkan kelompok siswa yang mempunyai sikap ilmiah dibawah rata-rata dengan nilai rata-rata 69,6. Begitu pula dengan penelitian yang telah dilakukan oleh Hifni dan Turnip(2015) yang melihat terdapat Perbedaan hasil postes Keterampilan proses sains siswa yang diajarkan dengan model pembelajaran inquiry training lebih baik dari siswa yang diajarkan dengan pembelajaran konvensional. Nilai rata-rata postes untuk kelas kontrol sebesar 62,28 dan nilai rata-rata untuk kelas eksperimen sebesar 74,56. 
Rima Nilmalasari dan Karya Sinulingga; Pengaruh Model Pembelajaran Inquiry Training Terintegrasi Powerpoint Terhadap Keterampilan Proses Sains Di Kelas X Semeseter II SMA Dharma Pancasila T.P $2017 / 2018$

Menurut hasil penelitian yang telah dilakukan Sakdiah dan Sahyar (2014) dengan melihat ada perbedaan nilai rata - rata pre-test dengan menggunakan model pembelajaran inquiry training 37,71 dan setelah diberikan perlakuan model pembelajaran inquiry training 72,71. Namun di kelas dengan menggunakan pembelajaran konvesional dengan nilai rata rata 34,14 dengan nilai rata - rata post-test 57,71.

Model pembelajaran inquiry training menggunakan media powerpoint lebih baik dalam meningkatkan keterampilan proses sains siswa daripada pembelajaran konvensional. Peningkatan keterampilan proses sains siswa juga didukung dengan peningkatan aktivitas belajar di kelas eksperimen pada saat proses belajar dikarenakan pada penerapan model inquiry training Terintegrasi powerpoint menuntut cara belajar siswa aktif untuk menemukan sendiri.

Peningkatan keterampilan proses sains di kelas eksperimen pada saat proses belajar karena model pembelajaran inquiry trainning terintegrasi powerpoint menuntut cara belajar siswa aktif dengan menemukan sendiri dengan pengawasan dan pemanduan dari guru maka hasil yang diperoleh tidak mudah dilupakan siswa. Model pembelajaran inquiry training memberikan kesempatan kepada peserta didik untuk menemukan konsep-konsep fisika. Siswa dalam hal ini aktif dan antusias untuk bekerjasama dengan teman satu kelompok dalam menemukan dan menyelidiki konsepkonsep fisika yang telah diberikan oleh peneliti. Pembelajaran dengan model inquiry training membantu siswa membentuk cara kerja bersama yang efektif, saling membagi informasi, ketelitian, pengungkapan gagasan yang terstruktur serta mendengar dan menggunakan ide-ide orang lain. Siswa juga tertarik aktif saat berdiskusi saat diadakan diskusi antar kelompok. Konsep fisika yang dipelajari dihubungkan dengan kegiatan dalam kehidupan sehari-hari sehingga siswa tertarik untuk mempelajarinya.

Model pembelajaran inquiry training diterapkan dikelas eksperimen, peneliti menemukan beberapa kelebihan dan kekurangan. Adapun kelebihan dari model ini antara lain: menyebabkan siswa aktif dengan kegiatan belajarnya sendiri dengan melibatkan akalnya dalam menemukan dan melakukan eksperimen; menimbulkan rasa senang pada siswa, karena tumbuhnya rasa menyelidiki dan berhasil; menimbulkan rasa puas bagi siswa ; meningkatkan motivasi untuk belajar; memberikan pengalaman belajar bermakna daan meningkatkan kolaborasi antar siswa dan guru. Kepuasan batin ini mendorong ingin melakukan penemuan lagi sehingga minat belajarnya meningkat.

Kendala yang dihadapi peneliti yaitu kurangnya kesiapan siswa ketika menjawab pertanyaan-pertanyaan yang peneliti berikan. Penyebabnya karena sebelum memulai pembelajaran peserta didik tidak mempelajari materi terlebih dahulu. Keterbatasan peralatan praktikum membuat pembagian kelompok terlalu banyak sehingga lebih sulit mengontrol siswa yang kurang aktif dalam kegiatan kelompok. Pada saat peneliti menampilkan powerpoint siswa masih kurang mengerti pada konsep materi karena hanya terdapat gambar fenomena saja. Seharusnya peneliti memberikan materi dan penjelasan materi sebelum memulai sintaks agar siswa mudah memahami pertanyaan - pertanyaan yang di berikan. Peneliti menyediakan peralatan praktikum sesuai kelompok yang akan dibagi dan juga peneliti lebih memperdalam powerpoint ataupun bisa memasukkan animasi pada powerpoint agar siswa mudah memahami konsep dan merumuskan hipotesis.

\section{KESIMPULAN DAN SARAN}

\section{Kesimpulan}

Berdasarkan hasil penelitian yang telah dilaksanakan oleh peneliti dengan penelitian "Pengaruh Model Pembelajaran Inquiry Training Terintegrasi Powerpoint Terhadap Ketrampilan Proses Sains Siswa Kelas X Semester II SMA Swasta Dharma Pancasila Medan T.P 2017/2018" bahwa ada perbedaan nilai rata - rata dan aktivitas yang signifikan akibat pengaruh dari 
model pembelajaran inquiry training terintegrasi powerpoint terhadap keterampilan proses sains siswa pada materi pokok Momentum, Impuls dan Tumbukan kelas X SMA Dharma Pancasila Medan T.P 2017/2018.

\section{Saran}

Saran yang dapat peneliti ajukan sebagai berikut kepada peneliti selanjutnya agar memperdalam isi powerpoint yang akan ditampilkan yaitu dengan menambahkan beberapa animasi - animasi tentang materi sehingga powerpoint lebih menarik dan mudah dipahami. Model ini akan lebih baik apalagi perangkat disediakan lebih banyak untuk menghindari jumlah kelompok yang berlebihan. Hal ini bertujuan agar setiap anggota dalam tiap tiap kelompok lebih mudah diorganisir dan menyelesaikan diskusi kelompok sehingga peserta didik akan aktif dalam melakukan kegiatan berkelompok.

\section{DAFTAR PUSTAKA}

Arikunto, S., (2010), Prosedur Penelitian suatu Pendekatan Praktik, Rineka Cipta, Jakarta.

Diningrum, P.E.dan Harahap,M.B, (2017), Pengaruh Model Pembelajaran Inquiry Training Terhadap Keterampilan Proses Sains Siswa Pada Materi Pokok Fluida Dinamis Di Kelas Xi Semester Genap Man Lubuk Pakam T.A 2016/2017. Jurnal Pendidikan Fisika, 5(3);52-60.

Harlen, W. and Jos, E, (1994), Unesco Sourcebook For Sciencein The Primary School : A Workshop Approach To Teacher Education, Unesco Publishing, Unesco.Hidayat, M. I., dan Harahap, M. B, (2015), Efek Model Pembelajaran Inquiry Training Berbasis Multimedia Lectora Dan Kemampuan Berpikir Formal Terhadap Hasil Belajar Fisika Siswa.Jurnal Pendidikan Fisika, 1(4);2532.
Hidayat, M. I. dan Harahap, M. B, (2015), Efek Model Pembelajaran Inquiry Training Berbasis Multimedia Lectora Dan Kemampuan Berpikir Formal Terhadap Hasil Belajar Fisika Siswa.Jurnal Pendidikan Fisika, 1(4);25-32.

Hifni, M. dan Turnip, B.M., (2015) Efek Model Pembelajaran Inquiry Trainning Dan Kemampuan Berpikir Logis Terhadap Keterampilan Proses Sains Siswa.Jurnal Pendidikan Fisika, 1(4);9-16.

Joyce, B., Weil., M, and Calhoun, E, (2009)., model-model pengajaranedisi delapan, Pustaka Belajar, Yogyakarta.

Marpaung, F.dan Sahyar, (2016),Efek Model Pembelajaran Inquiry Trainingberbantuan Peta Konsep Dan Sikap IlmiahTerhadap Hasil BelajarKeterampilan Proses Sains Siswa. Jurnal Pendidikan Fisika,1(13);1-13.

Pani,N. dan Tarigan,R, (2016), Pengaruh Model Pembelajaran Inquiry Training Terhadap Keterampilan Proses Sains Siswa Pada Materi Pokok Suhu Dan Kalor Di Kelas X Semester II SMA Negeri 5 Medan. Jurnal Pendidikan Fisika,3(4);1-7.

Sakdiah, H. dan Sahyar, (2014), Efek Model Pembelajaran Inquiry Training Berbantukan Handout Dan Sikap Ilmiah Terhadap Kemampuan Siswa Berbasis Keterampilan Proses Sains (KPS).Jurnal Pendidikan Fisika, 2(3);33-39

Siahaan, S.A. dan Sahyar, (2017), Efek Model Pembelajaran Inquiry Training Terhadap Hasil Belajar Fisika Pada Materi Kalor Dan Perpindahannya Di SMP NEGERI 38 MEDAN Kelas VII Semster II. Jurnal Inpafi 5 (1): 69-76

Sinaga,V. dan Hutahaean,J, (2016), Pengaruh Model Pembelajaran Inquiry Training Terhadap Keterampilan Proses Sains 
Rima Nilmalasari dan Karya Sinulingga; Pengaruh Model Pembelajaran Inquiry Training Terintegrasi Powerpoint Terhadap Keterampilan Proses Sains Di Kelas X Semeseter II SMA Dharma Pancasila T.P $2017 / 2018$

Pada Materi Pokok Suhu Dan Kalor Kelas Semester II SMA Negeri 1

Sunggalt. P.2015/2016. Jurnal

Pendidikan Fisika.3(4);1-10. 